\title{
The anti-inflammatory and antinociceptive effects of proteins extracted from Acacia farnesiana seeds
}

\author{
LEAL, L.S.S."; SILVA, R.O.2; ARAUJO, T.S.L.'; SILVA, V.G.2, BARBOSA, A.L.R.2; MEDEIROS, J.V.R.2; \\ OLIVEIRA, J.S.*; ${ }^{*_{3}}$ VENTURA, C.A.* ${ }^{*_{1}}$ \\ -Universidade Federal do Piauí - Núcleo de Pesquisa de Biodiversidade e Biotecnologia (BIOTEC Campus de \\ Parnaíba-PI, Brasil. 2Universidade Federal do Piauí - Laboratório de Fisiofarmacologia Experimental - Campus de \\ Parnaíba-PI, Brasil. ' Universidade Federal do Piauí, Laboratório de Bioquímica de Micro-organismos e Plantas \\ (BIOMIC), Campus de Parnaíba-PI, Brasil. *Autor para correspondência: jsolivera@ufpi.edu.br
}

\begin{abstract}
Seeds of Acacia farnesiana are commonly sold in the local markets of northeastern Brazil as a therapeutic agent. The present work aimed to evaluate the anti-inflammatory and analgesic activities of proteins obtained from $A$. farnesiana seeds. Five different protein fractions (albumin, globulin, prolamin, acidic and basic glutelins) were obtained and investigated for the protein pattern, the presence of hemagglutinating and proteolytic activities. The globulin fraction (GLB) was also evaluated for anti-inflammatory and analgesic activities. Globulins reduced the paw edema induced by carrageenan in a dose-dependent manner, which was accompanied by a reduction of myeloperoxidase activity $(p<0.05)$. Additionally, GLB reduced the neutrophil peritoneal migration induced by carrageenan. However, GLB was not able to inhibit the edema triggered by dextran. Pre-treatment with globulins reduced the abdominal constrictions induced by acetic acid as well as the paw licking time induced by formalin ( $69.1 \%$ at first phase). However, it did not produce a significant antinociceptive effect in the hot plate test (55-56 $\left.{ }^{\circ} \mathrm{C}\right)$. Treating the GLB with heat (at $100^{\circ} \mathrm{C}$ for $30 \mathrm{~min}$ ) abolished its anti-edematogenic and hemagglutinating activities. Our results showed that seeds from $A$. farnesiana are a source of proteins with antiinflammatory and analgesic properties.
\end{abstract}

Keywords: cysteine proteinase, Coronha, inflammation, lectin, nociception

RESUMO: Efeito antiiflamatório e antinociceptivo de proteínas extraídas de sementes de Acacia farnesiana. Sementes de Acacia farnesiana são comumente vendidas em feiras locais no nordeste do Brasil como agente terapêutico. O presente trabalho objetivou avaliar as atividades antiinflamatória e antinociceptiva de proteínas obtidas de sementes de $A$. farnesiana. Cinco frações protéicas distintas (albuminas, globulinas, prolaminas, glutelinas ácidas e básicas) foram obtidas e investigadas quanto o perfil de proteínas, presença de atividade hemaglutinante e proteolítica. A fração globulina (GLB) também foi avaliada quanto a presença de atividade antiinflamatória e analgésica. Globulinas reduziram o edema de pata induzido por carragenina de modo dependente da dose que foi acompanhada da redução da atividade da mieloperoxidase $(p<0,05)$. Em adição, GLB reduziu a migração de neutrófilos para cavidade peritoneal induzida por carragenina. Entretanto, GLB não foi capaz de inibir o edema induzido por dextrana. O pré-tratamento com globulinas reduziu as contorções abdominais induzidas por ácido acético, bem como o tempo de lambedura da pata induzida por formalina $(69.1 \%$ na primeira fase). Por outro lado, GLB não produziu um efeito antinociceptivo significante no teste de placa quente $\left(55-56^{\circ} \mathrm{C}\right)$. O pré-tratamento de GLB com calor $\left(100^{\circ} \mathrm{C}\right.$ por $30 \mathrm{~min}$ ) aboliu sua atividade anti-edematogênica e hemaglutinante. Nossos resultados mostraram que sementes de $A$. farnesiana são fonte de proteínas com propriedades antiinflamatórias e analgésicas.

Palavras chave: proteases cisteínicas, Coronha, inflamação, lectina, nocicepção

Recebido para publicação em 03/02/2015

Rev. Bras. PI. Med., Campinas, v.18, n.1, p.38-47, 2016. 


\section{INTRODUCTION}

Acacia farnesiana (L.) Willd. is a plant belonging to the Leguminoseae family. The plant is mainly found in the tropical and subtropical regions of the globe (Yanis et al., 2010). In northeastern Brazil, the plant is commonly known as "Coronha" or "Jurema-branca," and different parts of the plant are widely used for their various pharmacological properties. According to Duke (1981), the bark of the plant is used as an astringent and demulcent, while other parts of the plant are used for medicinal purposes. Popularly, its gummy roots are chewed to alleviate sore throat pain, and the roots are used to alleviate diarrhea (Duke 1981, Morton 1981). An infusion of the flowers is used to help a stomachache, and leaf powder, when sprinkled onto wounds, is reported to acts as a healing agent (Morton 1981, Dwarakanath et al., 2013). Moreover, the pods of A. farnesiana are also used to treat a sore throat as well as conjunctivitis (Dwarakanath et al., 2013).

In addition to the popular uses, several reports have emphasized the pharmacological activities of $A$. farnesiana. An ethanolic extract obtained from its leaves was shown to exhibit anti-inflammatory and antimalarial activities and to have a gastric protection effect (Trivedi et al., 1986, Alarcon et al., 1994, Garavito et al., 2006). These activities are related to the presence of carotenoids, alkaloids, flavonoids and phenolic compounds in the plant (Trivedi et al., 1986, Seigler 2003). A previous phytochemical investigation of $A$. farnesiana seeds has revealed the presence of flavonoids and carotenoids, as well as some antioxidant activity (Hannachi et al., 2011).

Seeds of $A$. farnesiana are commonly sold in the local market of Parnaíba, Piauí, in northeast Brazil, and they are indicated to treat sore throat pain. The studies about the seeds' protein content in this plant are still incipient. For the genera Acacia, there are a few publications reporting that antiinflammatory and antitumor properties are displayed by molecules extracted from their seeds (Jayatilake et al., 2003, Abbouyi et al., 2004). However, the activities investigated in these studies are related to secondary metabolites, rather than to proteins.

Many publications have described the pharmacological activities displayed by various plant proteins (Hale et al., 2005, Oliveira et al., 2010), including those belonging to the Leguminoseae family (Leite et al., 2012). These plant proteins receive special attention, as they are promising molecules for human therapeutic treatment. Recently, Abrantes et al. (2013) purified a lectin-like protein with anti-inflammatory activity from albumin fraction A. farnesiana. In the present work, we evaluated the presence of anti-inflammatory and analgesic activities in the globulin fraction obtained from $A$. farnesiana seeds. Moreover, a possible mechanism for the observed effects is also proposed.

\section{MATERIALS AND METHODS \\ Drugs and reagents}

$\lambda$-Carrageenan, indomethacin, dextran sulfate, acetic acid, formaldehyde, were purchased from Sigma Chemical (Saint Louis, MO, USA). Heparin and morphine were provided by Merck, São Paulo, Brazil. Reagents for electrophoresis were obtained from GE Healthcare Brasil. All other chemicals were of analytical grade and obtained from standard commercial suppliers.

\section{Plant material and protein extraction}

A. farnesiana seeds were collected in Parnaíba, in the state of Piauí, Brazil. The plant was identified at Herbário Delta do Parnaíba (Universidade Federal do Piauí) and a voucher (N.252) was deposited to access the botanical material. Protein fractions were obtained according to methodology described by Soares et al., 2007. The seeds were ground to a fine powder, and the proteins were extracted by stirring $5 \mathrm{~g}$ of the seed flour in $50 \mathrm{~mL}$ of $500 \mathrm{mM} \mathrm{NaCl}$ for $4 \mathrm{~h}$ at $25^{\circ} \mathrm{C}$, followed by centrifugation for $20 \mathrm{~min}$ at $5,000 \times \mathrm{g}$ and $4{ }^{\circ} \mathrm{C}$. The resulting pellet was kept separate, and the supernatant was dialyzed against distilled water at $25^{\circ} \mathrm{C}$ for $72 \mathrm{~h}$ and centrifuged $\left(5,000 \times \mathrm{g}\right.$ and $4{ }^{\circ} \mathrm{C}$ for $20 \mathrm{~min}$ ) to separate the albumins (ALB) from the globulins (GLB). Both fractions were freeze-dried and stored until use. The prolamin fraction (PRO) was obtained by stirring the initial pellet with $50 \mathrm{~mL}$ of $70 \%$ (v/v) ethanol for $1 \mathrm{~h}$ at $25^{\circ} \mathrm{C}$. After centrifugation, the resulting supernatant was dialyzed against distilled water and freeze-dried as previously described. The new pellet was stirred in $50 \mathrm{~mL}$ of $100 \mathrm{mM} \mathrm{HCl}$ to obtain the acidic glutelins (AG). After another round of centrifugation, this supernatant was also dialyzed against distilled water and freeze-dried. The remaining pellet was stirred for 1 additional hour in $50 \mathrm{~mL}$ of $100 \mathrm{mM} \mathrm{NaOH}$ to obtain the basic glutelins (BG). Another round of centrifugation followed, and this fourth supernatant was dialyzed against distilled water and freeze-dried.

\section{Protein determination}

One milligram of each protein fraction was dissolved in $1 \mathrm{~mL}$ of $150 \mathrm{mM} \mathrm{NaCl}$. The soluble proteins were measured according to the Bradford (1976) procedure, with bovine serum albumin as the protein standard.

SDS-PAGE

Polyacrylamide gel electrophoresis in the

Rev. Bras. PI. Med., Campinas, v.18, n.1, p.38-47, 2016. 
presence of SDS (SDS-PAGE) was performed as described by Laemmli (1970).

\section{detection}

Hemagglutination assays for lectin

Samples $(1 \mathrm{mg} / \mathrm{mL})$ of each protein fraction were diluted serially (2-fold) in a 96-well microtiter $\mathrm{U}$-bottom plate. The samples were mixed with 100 $\mu \mathrm{L}$ of a $2 \%$ suspension of either type $A, A B, B$ or $\mathrm{O}$ human erythrocytes. The plate was left at room temperature for $12 \mathrm{~h}$, and the end-point showing the minimum level of hemagglutination was determined. The hemagglutinating potency was expressed as hemagglutinating units (Ramos et al., 2002).

\section{Detection of proteinases by zymography}

After electrophoresis of $12.5 \%$ polyacrylamide gels containing $0.1 \%$, gels were immersed in water containing $2.5 \%$ Triton X-100 and gently shaken for $30 \mathrm{~min}$ at $25{ }^{\circ} \mathrm{C}$ to wash out the SDS and allow for protein rearrangement. The gels were then incubated in $50 \mathrm{mM}$ acetate buffer $(\mathrm{pH}$ 5.0 ) in the presence or absence of $3 \mathrm{mM}$ DTT for 16 $\mathrm{h}$ at $37^{\circ} \mathrm{C}$. The enzymatic activity was detected as transparent bands on the gel (Oliveira et al., 2010).

\section{Animals}

Animal experiments were performed on male Swiss mice (Mus musculus, $20-30 \mathrm{~g}$ ) and male Wistar rats (Rattus norvegicus, $180-200 \mathrm{~g}$ ) that were obtained from the Animal Breeding Facility of the Universidade Federal do Ceará. The animals were maintained under standard conditions, with a $12 \mathrm{~h}$ light-dark cycle and at $27^{\circ} \mathrm{C}$, and had free access to water and food. All experimental procedures were carried out in accordance with the guidelines of the UFPI Animal Ethics Committee, following their approval of the experiment (Protocol Number 041/2014).

\section{Anti-inflammatory activity \\ Paw edema and myeloperoxidase (MPO) measurement}

Paw edema was induced in the mice by carrageenan $(\mathrm{Cg}, 500 \mu \mathrm{g} / \mathrm{paw})$ and in the rats

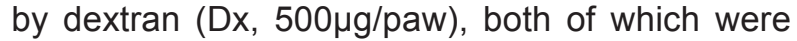
prepared in saline according to methodology described by Winter et al., 1962. A volume of 0.1 $\mathrm{mL}$ was injected via the sub plantar route into the right hind paw of the animal. The paw volume was measured immediately before the irritant injection and at selected time intervals thereafter (at 1,2, 3 and 4 hours for $\mathrm{Cg}$ and at $30 \mathrm{~min}, 1,2,3$ and 4 hours for Dx) using a hydroplethysmometer. The globulin fraction $(1,3,10$ or $30 \mathrm{mg} / \mathrm{kg}$ ) dissolved in $0.1 \mathrm{~mL}$ saline was injected intraperitoneally (i.p.) 30 min before the injection of carrageenan or dextran.
In these experiments, the control group received only sterile saline (i.p.). Indomethacin (INDO, $10 \mathrm{mg} / \mathrm{kg}$, i.p.) was injected $30 \mathrm{~min}$ before the inflammatory stimulus as a positive control for paw edema inhibition. The results were expressed as the increase in paw volume $(\mathrm{mL})$, which was calculated by subtracting the basal volume.

In an additional experiment, GLB was submitted to a heat treatment $\left(100^{\circ} \mathrm{C}\right.$ for $30 \mathrm{~min}$ ) for promoting protein denaturation. Following the heat, the denatured GLB (30 mg/kg, i.p.) was injected into the mice 30 min before the carrageenan injection was administered. The paw volume was measured as described above.

MPO is an enzyme found primarily in neutrophil azurophilic granules that has been used extensively as a biochemical marker for granulocyte infiltration into tissues (Bradley et al., 1982). The paw tissue myeloperoxidase activity was determined on globulin-treated animals (30 mg/kg, i.p.) four hours later carrageenan administration to determine a pattern of neutrophil accumulation in the mouse paw.

\section{Peritonitis model}

Peritonitis was induced in the mice by the intraperitoneal administration of a $1 \%$ solution of carrageenan $(500 \mu \mathrm{g} /$ cavity). The animals were sacrificed $4 \mathrm{~h}$ after drug administration, and the peritoneal cavity was washed with $3 \mathrm{~mL}$ of sterile saline containing $5 \mathrm{IU} / \mathrm{mL}$ of heparin. The total and differential leukocyte counts were determined in the fluid recovered from the peritoneal cavity (Souza \& Ferreira 1985). Globulins (30mg/kg, i.p.) were injected 30 min before the carrageenan injection, and its effect on the leukocyte counts was evaluated. A comparison was made with the control group that received only sterile saline (i.p.). Indomethacin (10 $\mathrm{mg} / \mathrm{mL}$, i.p.) was used as a positive control for antiinflammatory activity.

\section{Antinociceptive activity}

Acetic acid-induced writhing

Mice were injected i.p. with $0.6 \%$ acetic acid (10 mL/kg body weight). After $10 \mathrm{~min}$, a recording of the number of constrictions was begun that lasted for $20 \mathrm{~min}$, as has been previously described (Koster et al., 1959). In the experimental group, the animals were pretreated (i.p.) with the globulin fraction (30 $\mathrm{mg} / \mathrm{kg}$ ) $30 \mathrm{~min}$ before the acetic acid administration. The control animals were injected with sterile saline (0.5 mL). Morphine (5 mg/kg, subcutaneously) was used as a reference drug.

\section{Formalin test}

Animals were pretreated with either the globulin fraction (30 mg/kg, i.p.) or morphine (5 $\mathrm{mg} / \mathrm{kg}$, s.c.) $30 \mathrm{~min}$ before the administration of 20

Rev. Bras. PI. Med., Campinas, v.18, n.1, p.38-47, 2016. 
$\mu \mathrm{L}$ of $1.2 \%$ formalin to the right hind paws of the mice. The licking time was determined in two time ranges, from 0 to 5 min (phase 1, neurogenic) and from 20 to 25 min (phase 2, inflammatory), after the intraplantar formalin injection, according to Fasmer et al., (1985). Control animals were injected with sterile saline $(0.5 \mathrm{~mL})$.

\section{Hot plate test}

For the hot plate test, mice were submitted to a plate heated to $55-56^{\circ} \mathrm{C}$ according to methodology of Eddy \& Leinback (1953), with some modifications. Mice were treated with a globulin fraction dose of 30 $\mathrm{mg} / \mathrm{kg}$ (i.p.), and the control group received sterile saline $(0.5 \mathrm{~mL})$. Measurements were performed at time zero ( $0 \mathrm{~min})$ and at $30,60,90$ and $120 \mathrm{~min}$ after the protein fraction administration. The hot plate cut-off time was $45 \mathrm{~s}$ to avoid animal paw lesions. Morphine (5 mg/kg, s.c.) was used as a reference drug.

\section{Statistical analysis}

The results are given as the means \pm S.E.M. For the antinociceptive studies, paw edema models and MPO measurements, the statistical analysis was performed by ANOVA followed by Newman Keuls tests. For the peritonitis model experiments, the statistical analysis was performed by ANOVA followed by Bonferroni's test. The difference was considered statistically significant at $p<0.05$ for both sets of experiments.

\section{RESULTS}

Protein fractions obtained from the crude saline extract of the $A$. farnesiana seed flour were characterized for their protein content and analyzed by polyacrylamide gel electrophoresis. These fractions were also examined for the presence of hemagglutination activity against different human blood group erythrocytes to show the presence of lectin.

The protein content was further evaluated by SDS-PAGE (Figure1). An analysis of the protein pattern in all of the fractions revealed the presence of proteins with molecular weights ranging from 14.4 to $66.0 \mathrm{kDa}$, with a $30.0 \mathrm{kDa}$ band representing the primary protein present in the GLB and AG fractions. The diversity of observed proteins over all fractions confirms that the fractionation procedure was successful. While no soluble proteins were estimated by the Bradford method in the PRO and BG fractions, as shown in Table 1, low protein amounts were detected by SDS-PAGE. The soluble protein contents in these fractions are likely subestimated because their proteins are poor in or absent of the arginine and aromatic amino acids

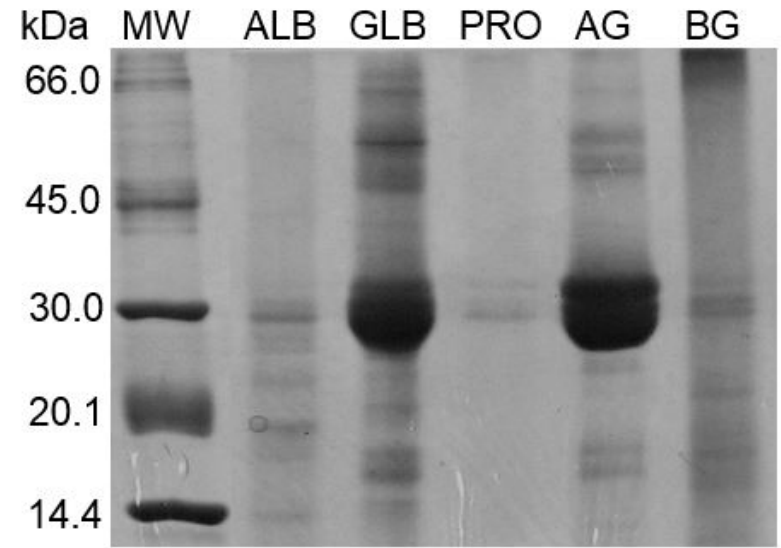

FIGURE 1. Polyacrylamide gel electrophoresis $(12.5 \%)$ of the albumin (ALB), globulin (GLB), prolamin (PRO), acidic glutelin (AG) and basic glutelin (BG) protein fractions from $A$. farnesiana seeds. Samples of $10 \mu \mathrm{g}$ from each protein fraction were loaded into the gel. Molecular weight markers: $66.0 \mathrm{kDa}$ albumin; $45.0 \mathrm{kDa}$ ovalbumin; $30.0 \mathrm{kDa}$ carbonic anhydrase; $20.1 \mathrm{kDa}$ trypsin inhibitor and $14.4 \mathrm{kDa}$ lactalbumin.

which are detected by the Bradford methodology.

Table 1 summarizes the protein content of each protein fraction, as well as the lectin activity. GLB was the protein fraction richest in both soluble proteins and hemagglutinating activity. This protein fraction was able to agglutinate type $A, A B$ and $O$ human erythrocytes. PRO and ALB were devoid of such activity against any tested erythrocytes. The acidic and basic glutelins were found to be specific to blood type $A$, despite the fact that no soluble proteins were found in the $B G$ fraction. None of the tested protein fractions was able to promote visible hemagglutination of blood type $B$ at the tested protein concentrations.

The globulin fraction presented the best performance in the hemagglutination assay using human red cells. For this reason, this fraction was chosen for further examination, evaluating its antiinflammatory and antinociceptive activities. Table 2 shows the effects of GLB on the paw edema of experimental animals.

As expected, treatment with carrageenan induced a significant increase in paw volume $(p<$ $0.05)$. A significant reduction of edema was observed in all groups treated with GLB prior to carrageenan treatment, beginning within one hour and lasting until the fourth hour after $\mathrm{Cg}$ administration $(p<0.05)$. This inhibitory effect on the paw edema induced by carrageenan was dose-dependent, and the maximum effect occurred in animals that were given a dose of $30 \mathrm{mg} / \mathrm{kg}$ GLB.

In an additional experiment, GLB (30 mg/kg)

Rev. Bras. PI. Med., Campinas, v.18, n.1, p.38-47, 2016. 
TABLE 1. The protein content and hemagglutination activity on human erythrocytes of the protein fractions isolated from $A$. farnesiana seeds.

\begin{tabular}{lccccc}
\hline \multirow{2}{*}{ Protein fraction } & \multirow{2}{*}{ Soluble proteins $(\mathbf{m g} / \mathbf{m L})^{*}$} & \multicolumn{3}{c}{ Human blood group erythrocytes $(\mathrm{HU})$} \\
\cline { 2 - 6 } & & A & B & AB & O \\
\hline Albumin & 0.52 & ND & ND & ND & ND \\
Globulin & 1.92 & 2 & ND & 1 & 1 \\
Prolamin & ND & ND & ND & ND & ND \\
Acidic glutelin & 0.26 & 2 & ND & ND & ND \\
Basic glutelin & ND & 2 & ND & ND & ND \\
\hline
\end{tabular}

A $2 \%$ erythrocyte solution was used in this assay. ND: not detected. *The protein concentration was determined by the Bradford method after the solubilization of $1 \mathrm{mg}$ of each protein fraction. $\mathrm{HU}$ : hemagglutinating units.

was submitted to denaturing conditions by heating at $100^{\circ} \mathrm{C}$ for 30 min prior to carrageenan administration in paw edema model. Four hours after inflammatory stimuli, the paw volume of the animals treated with denatured GLB was measured $(0.030 \pm 0.006 \mathrm{~mL})$ and no significant differences was observed when compared to carrageenan group $(0.039 \pm 0.004$ $\mathrm{mL})(p>0.05)$. Data shown that the heat treatment procedure extinguished the anti-edematogenic effect of GLB. Moreover, denatured GLB was also lacking in hemagglutination activity (Data not shown).

The anti-inflammatory activity of the globulin fraction, evaluated on a paw edema model, was also confirmed by the measurement of myeloperoxidase (MPO) activity in carrageenan-inflamed tissues (Figure 2). GLB (30 mg/kg) consistently inhibited neutrophil accumulation in paw edemas, as determined by MPO activity. Furthermore, the antiedematogenic effect promoted by the globulins was similar to that of indomethacin $(p>0.05)$, a commercial drug used as an anti-inflammatory agent (Table 2 and Figure 2). On the other hand, these results showed that GLB (30 mg/kg) did not affect the dextran-induced edematogenic effect at all (Table 2).

The anti-inflammatory activity of GLB was also evaluated in a peritonitis model using carrageenan as the inflammatory stimuli. Figure 3 shows that the intraperitoneal administration of carrageenan produced a significant increase in the peritoneal cavity neutrophil count of the animals $\left(2,482.0 \pm 402.7 \times 10^{3}\right.$ neutrophils $\left./ \mathrm{mL}\right)$, when compared to animals treated only with sterile saline $\left(1,112.0 \pm 172.5 \times 10^{3}\right.$ neutrophils $\left./ \mathrm{mL}\right)(p<0.05)$. Pre-treating the animals with GLB reduced the neutrophil migration $\left(567.0 \pm 803.0 \times 10^{3}\right.$ neutrophils/ $\mathrm{mL}$ ) to a level comparable with those observed in the saline and indomethacin groups $(p>0.05)$.

The antinociceptive activity of the globulin

TABLE 2. The anti-inflammatory activity of the globulin fraction from $A$. farnesiana seeds on paw edema that was induced by either carrageenan or dextran.

\begin{tabular}{|c|c|c|c|c|c|c|}
\hline \multirow{2}{*}{ Group } & \multirow{2}{*}{$\begin{array}{c}\text { Dose } \\
(\mathrm{mg} / \mathrm{kg})\end{array}$} & & \multicolumn{4}{|c|}{ Paw edema in mL (inhibition \%) } \\
\hline & & $30 \mathrm{~min}$ & $1 \mathrm{~h}$ & $2 \mathrm{~h}$ & $3 \mathrm{~h}$ & $4 \mathrm{~h}$ \\
\hline \multicolumn{7}{|c|}{ Animals treated with carrageenan $(500 \mu \mathrm{g} / \mathrm{paw})$} \\
\hline (1)Saline & - & - & $0.006 \pm 0.004$ & $0.004 \pm 0.004$ & $0.006 \pm 0.004$ & $0.004 \pm 0.004$ \\
\hline $\mathrm{Cg}$ & - & - & $0.050 \pm 0.005^{a}$ & $0.050 \pm 0.005^{a}$ & $0.060 \pm 0.006^{a}$ & $0.060 \pm 0.005^{\mathrm{a}}$ \\
\hline INDO & 10 & - & $0.022 \pm 0.004^{\mathrm{b}}(56.0 \%)$ & $0.020 \pm 0.002^{\mathrm{b}}(60.0 \%)$ & $0.040 \pm 0.008^{b}(33.3 \%)$ & $0.030 \pm 0.002^{b}(50.0 \%)$ \\
\hline GLB & 1 & - & $0.030 \pm 0.005^{b}(40.0 \%)$ & $0.030 \pm 0.005^{\natural}(40.0 \%)$ & $0.040 \pm 0.008 \mathrm{~b}(33.3 \%)$ & $0.040 \pm 0.008^{b}(33.3 \%)$ \\
\hline GLB & 3 & - & $0.020 \pm 0.004^{b}(60.0 \%)$ & $0.020 \pm 0.004^{\mathrm{b}}(60.0 \%)$ & $0.020 \pm 0.003^{\mathrm{b}}(66.7 \%)$ & $0.030 \pm 0.003^{b}(50.0 \%)$ \\
\hline GLB & 10 & - & $0.020 \pm 0.004^{\mathrm{b}, \mathrm{c}}(60.0 \%)$ & $0.010 \pm 0.005^{\mathrm{b}, \mathrm{c}}(80.0 \%)$ & $0.020 \pm 0.005^{\mathrm{b}, \mathrm{c}}(66.7 \%)$ & $0.030 \pm 0.007 \mathrm{~b}, \mathrm{c}(50.0 \%)$ \\
\hline GLB & 30 & - & $0.020 \pm 0.008^{\mathrm{b}, \mathrm{c}}(60.0 \%)$ & $0.007 \pm 0.004^{\mathrm{b}, \mathrm{c}}(86.0 \%)$ & $0.010 \pm 0.006 \mathrm{b,c}(83.3 \%)$ & $0.010 \pm 0.006^{\mathrm{b}, \mathrm{c}}(83.3 \%)$ \\
\hline \multicolumn{7}{|c|}{ Animals treated with dextran $(500 \mu \mathrm{g} / \mathrm{paw})$} \\
\hline (2)Saline & - & $0.115 \pm 0.021$ & $0.123 \pm 0.022$ & $0.100 \pm 0.035$ & $0.103 \pm 0.035$ & $0.113 \pm 0.022$ \\
\hline Dx & - & $0.822 \pm 0.067^{d}$ & $0.780 \pm 0.060^{d}$ & $0.780 \pm 0.090^{d}$ & $0.650 \pm 0.065^{d}$ & $0.522 \pm 0.081^{d}$ \\
\hline GLB & 30 & $\begin{array}{c}0.767 \pm 0.059 \\
(6.7 \%)\end{array}$ & $0.632 \pm 0.075(19.0 \%)$ & $0.617 \pm 0.059(20.9 \%)$ & $0.505 \pm 0.040(22.3 \%)$ & $0.437 \pm 0.050(16.3 \%)$ \\
\hline
\end{tabular}

Values are given as the means \pm S.E.M. of five animals, as analyzed by ANOVA followed by Newman Keuls test $(p<0.05)$. Cg: carrageenan, Dx: dextran, INDO: indomethacin, GLB: globulins. aCompared with saline group (1); ' $C o m p a r e d$ with the carrageenan group; 'Compared with the GLB group (1 mg/mL); 'Compared with saline group (2). 
fraction was studied in three distinct experimental models. In the acetic acid-induced writhing model, the globulin fraction showed a potent antinociceptive effect. An inhibition rate of $91.1 \%$ was achieved compared to the control (Table 3). The reference drug morphine inhibited the abdominal constrictions by $98 \%$. No significant difference was observed between the GLB and morphine groups ( $p>0.05$ ).

The evaluated protein fraction also exhibited a strong analgesic effect in the formalin test (Figure 4). Treating the animals with a $30 \mathrm{mg} / \mathrm{kg}$ dose of the globulin fraction reduced the paw licking time in the first phase $(69.1 \% ; p<0.05)$. However, no statistical significance was observed with the control in the second phase $(31.0 \% ; p>0.05)$. As expected, the reference drug morphine significantly inhibited the formalin-induced paw licking in both phases.

Table 4 shows the antinociception measured in animals during the hot plate test. As expected, morphine showed a potent analgesic response after the stimuli when compared to the control animals. On the other hand, a dose of $30 \mathrm{mg} / \mathrm{kg}$ GLB administered by the i.p. route did not increase the reaction time at the different tested intervals, when compared to the control $(p>0.05)$.

Finally, zymography was performed on an electrophoresed polyacrylamide gel containing $0.1 \%$ gelatin to verify the presence of proteinases in all of the protein fractions. As shown in Figure 5 , the presence of transparent bands indicates that proteolytic activity was found in the albumin and basic glutelin fractions. The positive result for

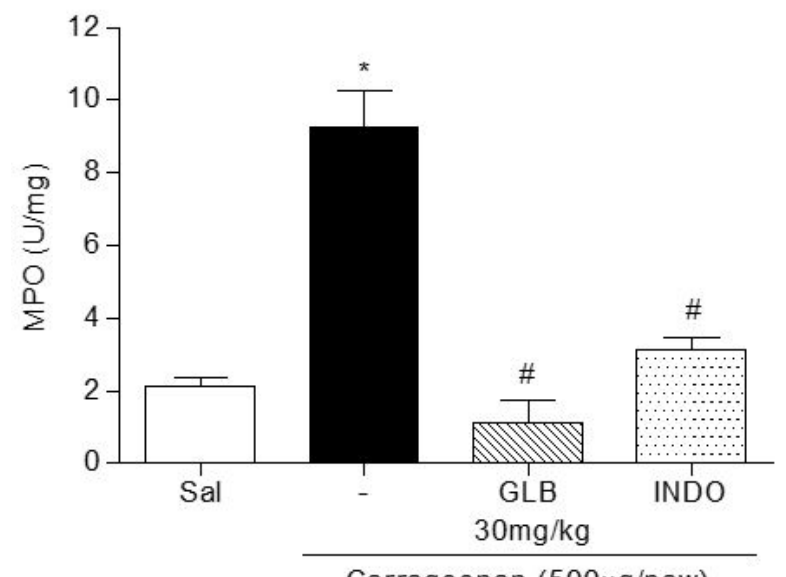

Carrageenan $(500 \mu \mathrm{g} / \mathrm{paw})$

FIGURE 2. The inhibitory effects of the globulin fraction $(30 \mathrm{mg} / \mathrm{kg})$ from $A$. farnesiana seeds on MPO activity, as measured in the paw edema tissue of animals given an intraplantar injection of carrageenan. The values given are the means \pm S.E.M. $(\mathrm{n}=5)$. Indomethacin $(10 \mathrm{mg} / \mathrm{kg}$, i.p.) was used as a positive control. ${ }^{*} p<0.05$ compared to saline, $\# p<0.05$ compared to carrageenan (ANOVA followed by Neuman Keuls post-test). basic glutelin in the 3mM DTT treated gel indicates the presence of cysteine proteinase activity in this fraction (Figure 5C). GLB was lacking in such activities.

\section{DISCUSSION}

The search for new biologically active molecules from plants remains the main strategy to exploit drugs for pharmacological purposes (Alencar et al., 2004). Detecting the presence of active molecules in a plant extract is the first strategy in the study of potentially therapeutic plants (Soares et al., 2005). Indeed, the identification of active compounds is an important method to understand how such molecules trigger their pharmacological activities. This was the idea behind the present study. Proteins from the seeds of $A$. farnesiana, a widely used plant for medicinal purposes, were evaluated for their anti-inflammatory and analgesic effects and to detect active proteins.

After preparing flour from seeds of $A$. farnesiana, the proteins were fractionated by extraction with different solutions to obtain distinct, semi-purified fractions. The extraction procedure rendered five protein fractions (albumin, globulin, prolamin, acidic and basic glutelins) with differing protein solubilities (Ramos et al., 2002). All protein fractions were further evaluated for the presence of lectin and for their proteolytic activity. The pharmacological properties of the globulin fraction were also tested.

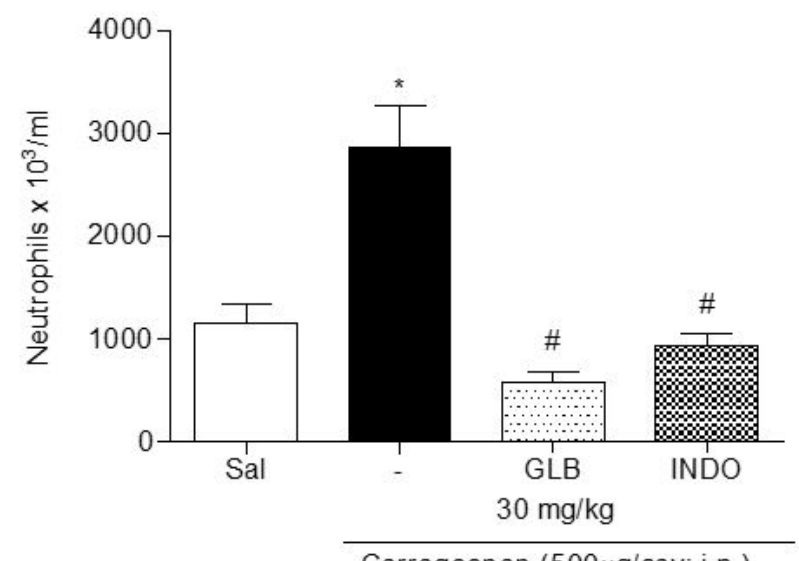

Carrageenan $(500 \mu \mathrm{g} / \mathrm{cav}$; i.p. $)$

FIGURE 3. The inhibitory effect of the globulin fraction $(30 \mathrm{mg} / \mathrm{kg})$ from $A$. farnesiana seeds on the neutrophil migration induced by carrageenan in a peritonitis model. The values given are the means \pm S.E.M. $(n=5)$. Indomethacin $(10 \mathrm{mg} / \mathrm{kg}$, i.p. $)$ was used as a positive control for the anti-inflammatory activity. ${ }^{*} p<0.05$ compared to saline, $\# p<0.05$ compared to carrageenan (ANOVA followed by Bonferroni's post-test). 
TABLE 3. The antinociceptive effect of the globulin fraction from A. farnesiana seeds on acetic acid induced writhing.

\begin{tabular}{|c|c|c|}
\hline Group & Abdominal constrictions (20 $\mathrm{min})$ & Inhibition rate (\%) \\
\hline Saline & $29.67 \pm 6.24$ & - \\
\hline GLB (30 mg/kg) & $2.40 \pm 1.50^{a}$ & 91.1 \\
\hline Morphine $(5 \mathrm{mg} / \mathrm{kg})$ & $0.60 \pm 0.40^{a}$ & 98.0 \\
\hline
\end{tabular}

Values are given as the means \pm S.E.M. of five animals, as analyzed by ANOVA followed by NeumanKeuls test $(p<0.05)$. GLB: globulins. aCompared with the saline group.
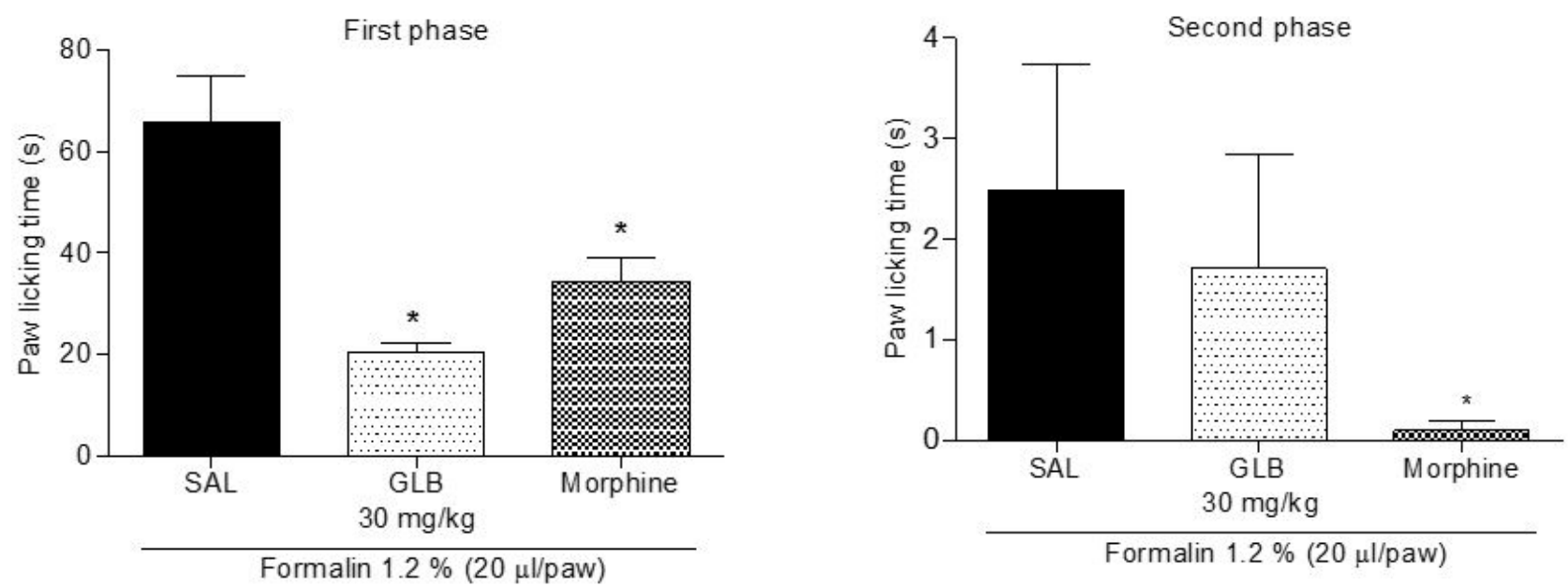

FIGURE 4. The antinociceptive effect of the globulin fraction $(30 \mathrm{mg} / \mathrm{kg})$ from $A$. farnesiana seeds in formalininduced paw licking. Morphine (5 mg/kg, i.p.) was used as a positive control for the antinociceptive effect. * $<$ 0.05 compared to saline (ANOVA followed by NeumanKeuls test).

TABLE 4. The antinociceptive effect of the globulin fraction from A. farnesiana seeds in the hot plate test.

\begin{tabular}{|c|c|c|c|c|c|}
\hline \multirow{2}{*}{ Group } & \multicolumn{5}{|c|}{ Reaction time (after stimuli administration) } \\
\hline & $0 \mathrm{~min}$ & $30 \mathrm{~min}$ & $60 \mathrm{~min}$ & $90 \mathrm{~min}$ & $120 \mathrm{~min}$ \\
\hline Saline & $5.9 \pm 2.5$ & $8.8 \pm 1.4$ & $7.3 \pm 2.0$ & $4.1 \pm 2.6$ & $7.6 \pm 1.7$ \\
\hline GLB (30 mg/kg) & $13.5 \pm 2.8$ & $8,3 . \pm 3.2$ & $7.4 \pm 2.9$ & $9.0 \pm 4.2$ & $5.2 \pm 5.3$ \\
\hline Morphine $(5 \mathrm{mg} / \mathrm{kg})$ & $15.1 \pm 2.7^{a}$ & $44.9 \pm 4.2^{\mathrm{a}}$ & $45.0 \pm 4.0^{a}$ & $21.7 \pm 6.7^{a}$ & $22.3 \pm 7.2^{\mathrm{a}}$ \\
\hline
\end{tabular}

Values are given as the means \pm S.E.M. of five animals, as analyzed by ANOVA followed by NeumanKeuls test $(p<0.05)$. GLB: globulins. aCompared with the saline group.

GLB proteins were able to inhibit the paw edema that was induced by carrageenan in a dosedependent manner. This effect was accomplished by a reduction of myeloperoxidase activity in the animal paw tissue at dose of $30 \mathrm{mg} / \mathrm{kg}$. However, the globulin fraction did not reduce dextran-induced paw edema. It is well documented that inflammatory events trigged by carrageenan involve cell migration, while those produced by dextran administration induce edema via resident cell degranulation (Lo et al., 1982). In addition, our results demonstrate that neutrophil migration was also inhibited in the peritonitis model, a well-characterized tool that allows for the quantification of acute neutrophil migration to the peritoneal cavity of experimental animals (Montanher et al., 2007). Thus, it is safe to assume that the anti-inflammatory activity of GLB $(30 \mathrm{mg} / \mathrm{kg})$ is cell-mediated. Similar results were observed in the work developed by Soares et al. (2012). The authors showed that proteins obtained from Abelmoschus esculentus seeds exhibited anti-inflammatory activity in the paw edema model induced by carrageenan. However, no effect was observed against inflammation induced by dextran.

Many publications have emphasized that some plant seed lectins inhibit inflammation that is induced by carrageenan (Assreuy et al., 1997, Leite et al., 2012). These proteins have the ability to bind specifically and reversibly to carbohydrates and glycoconjugates and they can be detected through 


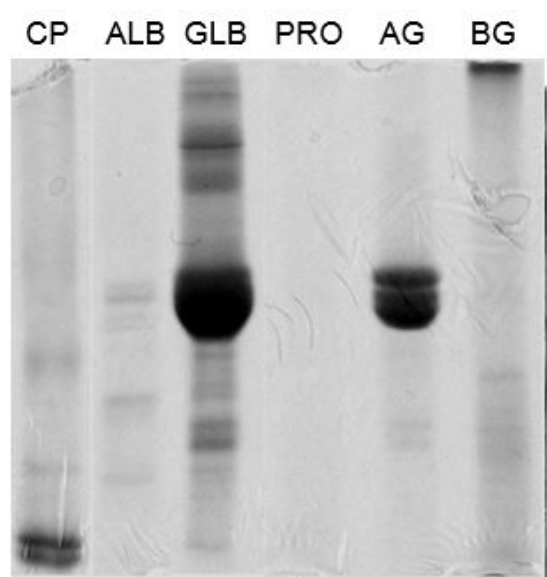

(A)

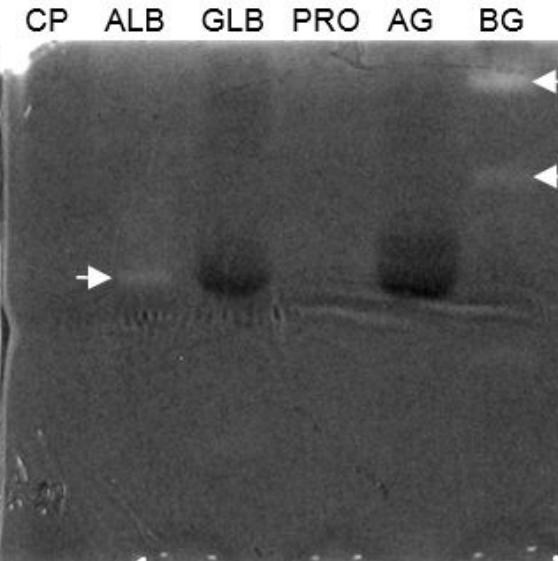

(B)
CP ALB GLB PRO AG BG

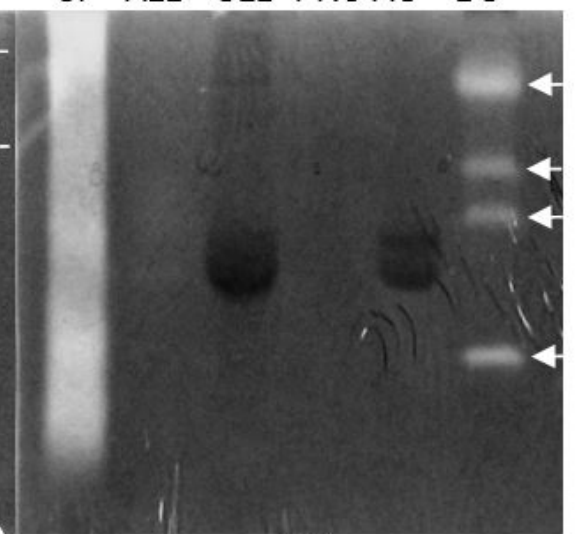

(C)

FIGURE 5. Zymography was performed on an electrophoresed SDS-PAGE (12.5\%) gel containing $0.1 \%$ gelatin to detect proteinase activity in the protein fractions from $A$. farnesiana seeds (A). Then, they were incubated in the absence (B) or presence of $3 \mathrm{mM}$ DTT $(C)$ to detect the total or specific cysteine proteinase activities, respectively. A protein fraction from Calotropis procera latex $(\mathrm{CP})$ was used as a positive control for the presence of cysteine proteinase activity. Arrows indicate the presence of proteolytic activity in the protein fractions from A. farnesiana seeds.

hemagglutination assay (Peumans \& Van Damme 1995). The proposed anti-inflammatory activity of lectins could be due to a blockage of neutrophilselectin carbohydrate ligands, inhibiting important cell migration events (Bezerra et al 2014). The GLB proteins hemagglutinated human erythrocytes of types $A, A B$ and $O$, suggesting the presence of lectin activity in this fraction. According to these results, we propose that the lectin present in the globulin fraction is involved in anti-inflammation activity observed.

In addition to lectins, plant cysteine proteinases were also shown to alleviate the inflammatory process (Hale et al., 2005). However, our results suggest that no proteolytic activity is involved in the anti-inflammatory effects promoted by GLB, because proteolytic activity was not found in it but was detected in other fractions.

Taking into consideration the close correlation observed between painful sensation development and the inflammatory process, three set of experiments were conducted to investigate the possible antinociceptive effects of GLB in mice. Interesting results were observed in the analgesic effects of the evaluated protein fraction. The globulins reduced the abdominal constrictions caused by acetic acid as well as the paw licking time induced by formalin. However, it did not have a significant antinociceptive action in the hot plate test. It has been widely reported that the hot plate test is a specific central antinociceptive test in which opioid agents exert their analgesic effects via supra spinal and spinal receptors (Nemirovsky et al., 2001). On the other hand, the acetic acid-induced writhing causes pain indirectly due to the acute increaseing the levels of inflammatory mediators. These mediators, such as biogenic amines, cyclooxygenases and their metabolites, stimulate peripheral nociceptive neurons and promote painful sensations (Ribeiro et al., 2000). In the formalin test, the pain in the mice paws involves two distinct phases. The first phase is characterized by neurogenic pain, caused by a direct chemical stimulation of the nociceptors and reflected centrally mediated pain. The second phase is characterized by inflammatory pain triggered by a combination of stimuli, including inflammation of the peripheral tissues and mechanisms of central sensitization (McNamara et al., 2007). According to these observations, and considering the fact that GLB did not increase the reaction time in the hot plate test, these results indicate that the proteins present in the GLB fraction do not act via supra spinal and spinal receptors. However, the positive results in the acetic acid-induced writhing and formalin tests indicate that the globulin fraction may act on pain processes by inhibiting inflammatory mediators. These observations are in agreement with other authors, which demonstrated that the antinociceptive activity of proteins recovered from plants involves inhibition of inflammatory mediators (Fernandes et al., 2015).

In the present work, we strongly suggest that the globulin fraction possesses lectin, which is involved in the observed effects. To reinforce our hypothesis, a testing sample of GLB (30 mg/kg) was submitted to a heat treatment $\left(30 \mathrm{~min}\right.$ at $\left.100{ }^{\circ} \mathrm{C}\right)$ prior to the anti-edematogenic and hemagglutinating activity studies. The protein denaturation by heat completely abolished GLB's active effects. Together,

Rev. Bras. PI. Med., Campinas, v.18, n.1, p.38-47, 2016. 
the results presented here indicate the participation of heat-sensitive lectin in the anti-inflammatory and antinociceptive activities of GLB. However, this hypothesis requires further experimental investigation.

Previously, Santi-Gadelha et al. (2008) purified a lectin (AFAL) from the albumin fraction of $A$. farnesiana seeds using the same extraction protocol described here. The authors showed that its hemagglutinating activity was observed only against rabbit erythrocytes, but not to human red blood cells. This observation was confirmed in our results, since no lectin activity against human erythrocytes were found in the albumin fraction, however the result was positive for globulins. Since lectins bind specifically to carbohydrate, and cell surface of erythrocytes from different species are characterized for different glycosylation pattern, we suppose that the pharmacological activities investigated in GLB are promoted by a lectin other than AFAL. Moreover, differences observed in the presence of proteolytic activity in albumins and globulin fractions reinforce the differences in protein content between fractions. These hypothesis suggest that the anti-inflammatory activity previously reported by AFAL (Abrantes et al., 2013) and pharmacolocgical activities observed here should be promoted by different lectins present in $A$. farnesiana seeds.

\section{CONCLUSION}

The experimental procedure developed here is of great importance because it investigates plant species as a source of molecules with specific activities. In the present work, we have confirms that proteins from the seeds of $A$. farnesiana possess anti-inflammatory and antinociceptive properties and such activities seem to be elicited, at least in parts, by lectins present in globulin fraction. Our data indicate that GLB promoted its pharmacological activities through events associated to inhibition of cell migration and release of inflammatory mediators.

\section{ACKNOWLEDGEMENTS}

The authors gratefully acknowledge the financial support from the National Counsel of Technological and Scientific Development (CNPq, Brazil), the Research Foundation for the State of Piauí (FAPEPI) and the Coordination for the Improvement of Higher Education Personnel (CAPES).

\section{REFERENCES}

ABBOUYI, A.E. et al. In vitro effects of aqueous seeds extract of Acacia cyanophylla on the opsonized zymosan-induced superoxide anions production by rat polymorphonuclear leukocytes. Journal of Ethnopharmacology, v.91, p.159-165, 2004.

ABRANTES, V.E.F. et al. Molecular Modeling of LectinLike Protein from Acacia farnesiana Reveals a Possible Anti-Inflammatory Mechanism in Carrageenan-Induced Inflammation. BioMed Research International, v.2013, p.1-9, 2013.

ALARCON, D.L.L.C. et al. Antiulcerogenic activity of flavonoids and gastric protection. Journal of Ethnopharmacoly, v.42, p.161-170, 1994.

ALENCAR, N.M.N. et al. Anti-inflammatory effect of the latex from Calotropis procera in three different experimental models: Peritonitis, Paw edema and Hemorrhagic cystitis. Planta Medica, v.70, p.11441149, 2004.

ASSREUY, A.M.S. et al. Antiinflammatory effect of glucosemannose binding lectins isolated from brazilian beans. Mediators of inflammation, v.6, p.201-210, 1997.

BEZERRA, G.A. et al. Structural Studies of an AntiInflammatory Lectin from Canavalia boliviana Seeds in Complex with Dimannosides. PLoS ONE, v.9, p.1-12, 2014.

BRADFORD, M.M. A rapid and sensitive method for the quantitation of microgram quantities for proteins utilizing the principle of protein-dye binding. Analytical Biochemistry, v.72, p.248-254, 1976.

BRADLEY, P.P. et al. Measurement of cutaneous inflammation: estimation of neutrophil content with anenzyme marker. Journal of Investigative Dermatology, v.78, p.206-209, 1982.

DUKE, J.A. Handbook of Legumes of World Economic Importance. 1 st edn. Plenum Press, New York and London, 1981. $345 \mathrm{p}$.

DWARAKANATH, V. et al. Anti-ulcer activity of Acacia farnesiana (L.) (Aroma) a lesser known folk - medicinal plant. International Journal of Pharmacy Biological Sciences, v.3, p.145-152, 2013.

EDDY, N.B.; LEIMBACH, D. Synthetic analgesics. II. Dithienylbutenyl and dithienylbutylamines. Journal of Pharmacology and Experimental Therapeutics, v.107, p.385-93, 1953.

FASMER, O.B. et al. Changes in nociception after lesions of descending serotonergic pathways induced with 5,6-dihydroxytryptamine. Different effects in the formalin and tail-flick tests. Neuropharmacology, v.24, p.729734, 1985.

GARAVITO, G. et al. Antimalarial activity of some Colombian medicinal plants. Journal of Ethnopharmacology, v.107, p.460-462, 2006.

FERANDES, H.B. et al. Laticifer proteins from Plumeria pudica inhibit the inflammatory and nociceptive responses by decreasing the action of inflammatory mediators and pro-inflammatory cytokines. Revista Brasileira de Farmacognosia, v.25, p.269-277, 2015.

HALE, L.P. et al. Proteinase activity and stability of natural bromelain preparations. International Immunopharmacology, v.5, p.783-793, 2005.

$\mathrm{HANNACHI}, \mathrm{H}$. et al. Chemicals profiling and antioxidants

Rev. Bras. PI. Med., Campinas, v.18, n.1, p.38-47, 2016. 
activities of Acacia seeds. Journal of Medicinal Plants Research, v.5, p.6869-6875, 2011.

JAYATILAKE, G.S. et al. Isolation and structures of avicins $D$ and $G$ : in vitro tumor-inhibitory saponins derived from Acacia victoriae. Journal of Natural Products, v.66, p.779-783, 2003.

KOSTER, R. et al. Acetic acid for analgesic screening. Federation Procedings, v.18, p.412, 1959.

LAEMMLI, U.K. Cleavage of structural proteins during the assembly of the bacteriophage T4. Nature, v.227, p.680-685, 1970.

LEITE, J.F.M. et al. Antinociceptive and anti-inflammatory effects of a lectin-like substance from Clitoria fairchildiana R. Howard Seeds. Molecules, v.17, p.3277-3290, 2012.

LO, T.N. et al. Dextran and carrageenin evoke different inflammatory response in rat with respect to composition of infiltrates and effect of indomethacin. Journal of Pharmacology and Experimental Therapeutics, v.221, v.261-267, 1982.

MCNAMARA, C.R. et al. TRPA1 mediates formalininduced pain. Proceedings of the National Academy of Sciences, v.104, p.13525-13530, 2007.

MONTANHER, A.B. et al. Evidence of anti-inflammatory effects of Passiflora edulis in an inflammation model. Journal of Ethnopharmacology, v.109, p.281-288, 2007.

MORTON, J.F. Atlas of medicinal plants of Middle America: Bahamas to Yucatan. 1st. C.C. Thomas, Springfield, IL, 1981. 1420p.

NEMIROVSKY, A. et al. The antinociceptive effect of the combination of spinal morphine with systemic morphine or buprenorphine. Anesthesia and Analgesia, v.93, p.197-203, 2001.

OLIVEIRA J.S. et al. In vivo growth inhibition of sarcoma 180 by latex proteins from Calotropis procera. Naunyn-Schmiedeberg's Archives of Pharmacology, v.382, p.139-149. 2010.

PEUMANS, W.J.; VAN DAMME, E.J. Lectins as plant defense proteins. Plant Physiology, v.109, p.347-352, 1995.

RAMOS, M.V. et al. Evidence of an endogenous lectin receptor in seeds of the legume Cratylia floribunda.
Brazilian Journal of Plant Physiology, v.4, p.195202, 2002.

RIBEIRO, R.A. et al. Involvement of resident macrophages and mast cells in the writhing nociceptive response induced by zymosan and acetic acid in mice. European Journal of Pharmacology, v.387, p.111-118, 2000.

SANTI-GADELHA, T. et al. Purification of a PHA-Like chitin-binding protein from Acacia farnesiana seeds: A Time-dependent oligomerization protein. Applied Biochemistry and Biotechnology, v.150, p.97-11, 2008.

SEIGLER, D.S. Phytochemistry of Acacia-sensu lato. Biochemical Systematics and Ecology, v.31, p.845873, 2003.

SOARES, E.L. et al. Characterization and insecticidal properties of globulins and albumins from Luetzelburgia auriculata (Allemao) Ducke seeds towards Callosobruchus maculatus (F.) (Coleoptera: Bruchidae). Journal of Stored Products Research, v.43, p.459467, 2007.

SOARES, P.M. et al. Antinociceptive activity of Calotropis procera latex in mice. Journal of Ethnopharmacology, v.99, p.125-129, 2005.

SOARES, G.S.F. et al. Purification and Biological Activities of Abelmoschus esculentus Seed Lectin. The Protein Journal, v.31, p.674-680, 2012.

SOUZA, G.E.P.; FERREIRA, S.H. Blockade by antimacrophage serum of the migration of PMN neutrophils into the inflammed peritoneal cavity. Agents Actions, v.17, p.1-5, 1985.

TRIVEDI, C.P. et al. Bronchodilator and anti-inflammatory effect of glycosidal fraction of Acacia farnesiana. . Indian Journal of Physiology and Pharmacology, v.30, p.267-268, 1986.

WINTER, C.A. et al. Carrageenin-induced edema in hind paw of the rat as an assay for antiiflammatory drugs. Proceedings of the Society for Experimental Biology and Medicine, v.111, p. 544-547, 1962

YANIS, B.K. et al. The evolutionary history and biogeography of Mimosoideae (Leguminosae): An emphasis on African acacias Original Research Article. Molecular Phylogenetics and Evolution, v.57, p.495508, 2010. 